\title{
IMPLIKASI KONSEP DAN DESAIN KURIKULUM DALAM TUGAS PEMBINAAN WARGA JEMAAT
}

\author{
Junihot M. Simanjuntak \\ Sekolah Tinggi Teologi Kharisma Bandung \\ junihots@gmail.com
}

\begin{abstract}
Abstrak
Tulisan ini bertujuan untuk memaparkan pentingnya para pendidik Kristen memahami konsep dan desain kurikulum dalam kaitannya dengan tugas pembinaan jemaat dan memaknainya sebagai tugas yang mendesak. Memakai metode deskriptif-analitis, penulis memaparkan konsep pembinaan warga jemaat, konsep dan desain kurikulum dalam pembinaan warga gereja. Hasil studi ini menunjukkan 1) Secara umum konsep pembinaan warga gereja di mana tujuan-tujuan pendidikan Kristen harus dimulai dari penegasan tentang Allah yang diperkenalkan melalui Kristus dalam Alkitab; 2) Konsep dan desain kurikulum dalam pembinaan warga gereja, dengan menyimak begitu banyak segi dari peran kurikulum, maka gereja tidak mungkin lagi mengabaikan tugas ini. Maka guru PAK di sekolah dan perguruan tinggi juga harus memikirkan pengembangan kurikulum. Salah satu aspek penting dari guru berkompetensi ialah kemampuannya dalam memahami, mengelola kurikulum dan pembelajaran. Di gereja, para pengerja dan pemimpinnya harus belajar merencanakan dan mengembangkan kurikulum pelayanan berbagai kategori dan kelompok warga gereja.
\end{abstract}

Kata-kata kunci: konsep, desain, kurikulum, tugas, pembinaan, gereja, warga jemaat

This article aims to explain the importance for Christian educators to understand the concept and design of curriculum in relationship to the task of teaching a congregation and understand it as an urgent task. Using the descriptive-analytic method, the writer explains the concept of teaching a congregation, and the concept and design of curriculum in teaching a congregation. The results of this study show l) Generally, concerning the concept of teaching a congregation, the goals of Christian education must begin with the statement about God, who is known through Christ in the Bible; 2) Concerning the concept and design of curriculum in teaching a congregation, including understanding the many-faceted role of curriculum, the church can no longer neglect this task. Accordingly, Christian education teachers both in schools and universities must think about curriculum development. One of the important aspects of a competent teacher is the 
capability to comprehend, organize curriculum, and teach. In the church, the staff and leaders must learn how to plan and develop curriculum to minister to the various categories and groups in the congregation.

Keywords: concept, design, curriculum, task, teaching, church, congregation

\section{Pendahuluan}

Kurikulum erat kaitannya dengan pembelajaran. Keduanya tidak terpisahkan. Kurikulum bukan hanya daftar isi bahan pelajaran yang harus ditempuh peserta didik. Kurikulum juga menyangkut masalah bagaimana isi bahan pelajaran disajikan oleh guru kepada muridnya supaya terjadi interaksi belajar bermakna guna mencapai tujuan yang diharapkan. Itu sebabnya pengertian kurikulum sekarang ini tidak lagi sebatas dokumen tertulis tentang apa saja yang harus dipelajari oleh peserta didik dalam sebuah kegiatan belajar, tetapi juga pengalaman belajar yang berlangsung. Kurikulum merupakan rencana belajar yang ditempuh peserta didik bersama dengan guru untuk mewujudkan tujuan yang ditetapkan.

Menyimak ide Peter F. Olivia, Wina Sanjaya mengemukakan empat model hubungan kurikulum dengan pembelajaran, yakni: 1) model dualistis (terpisah); 2) model berkaitan (interlocking); 3) model konsentris dimana pengajaran di lingkaran tengah dan kurikulum di lingkaran luar atau sebaliknya; 4) model siklus, keduanya saling terkait. ${ }^{1}$

Meskipun gereja adalah tubuh Kristus, umat Allah, dan persekutuan orang percaya, namun ia juga merupakan institusi (lembaga) yang membawa umat untuk bertumbuh dalam iman kepada Allah melalui Yesus Kristus, oleh firman-Nya. Gereja terpanggil untuk melaksanakan tugas pendidikan atau pembinaan warga jemaat. Howard dan Raymond mengemukakan lima alasan mengapa gereja harus memerlukan tugas ini yaitu: ${ }^{2}$

Pertama, karena diamanatkan oleh Tuhan Yesus Kristus, yakni memperlengkapi mereka yang percaya menjadi murid Tuhan (Matius 28:19-20). Kedua, Injil menghendaki adanya pembelajaran, supaya mereka yang telah mendengar dan percaya Yesus Kristus, bertumbuh dalam iman, juga semakin memahami Injil itu sendiri. Ketiga, sejarah

\footnotetext{
${ }^{1}$ Wina Sanjaya, Kurikulum dan Pembelajaran (Jakarta: Kencana Prenada Media Group, 2008), 20-21.

${ }^{2}$ Howard P. Colson dan Raymond M. Rigdon, Understanding Your Church's Curriculum (Nashville: Broadmann Press, 1981), 18-19.
} 
gereja menunjukkan bahwa dengan adanya pendidikan bagi warga, jemaat bertumbuh dan berkembang. Kisah Para Rasul saja menunjukkan bahwa jemaat mula-mula aktif dalam kegiatan belajar (Kis. 2:24). Rasul Paulus sendiri aktif mendidik dan mengajari jemaat supaya bertumbuh dalam relasi yang dinamis bersama Yesus Kristus. Mereka juga dimampukan untuk memaknai kehidupan dengan berbagai pergumulannya. Keempat, situasi zaman dimana gereja hidup menuntut pembinaan dan pendidikan. Nilai zaman yang berubah mengharuskan gereja melakukan tugas pendidikan dan pengajaran supaya mereka mampu membaca tanda-tanda zaman itu sendiri.

Kalau Amanat Agung Yesus hendak diwujudkan gereja, maka ia harus berpikir dan bertindak secara strategis. Dalam rangka menjadikan semua orang menjadi murid Yesus, pemberita Injil, pembaptisan dalam nama Bapa, Anak dan Roh Kudus, serta pengajaran supaya orang percaya menjadi pelaku ajaran Kristus, maka kurikulum dibutuhkan. Caranya ialah melalui perencanaan dan pengembangan kurikulum.

Campbell Wycoff mengemukakan bahwa gereja dipanggil oleh Tuhan melaksanakan tiga tugas penting yaitu: ${ }^{3}$

Pertama, beribadah, sebuah pelayanan yang menghubungkan komunitas orang percaya kepada Sang Pencipta, Hakim, Bapa Yang Mahakasih, Juruselamat dan sumber kekuatan serta bimbingan. Kedua, bersaksi yakni mengaktualkan pengalaman jemaat yang ditebus dan diperdamaikan kepada orang sekelilingnya supaya juga menjadi pengalaman mereka. Ketiga, berkarya dalam nama Yesus dalam rangka mengemban misi dan pelayanan Kristus dalam berbagai ragam dan situasi.

Selanjutnya Campbell Wycoff pun mengemukakan bahwa melalui tugas pendidikan Kristen, gereja membina kehidupan warganya. Oleh sebab itu dibutuhkan kurikulum, sebuah rencana kegiatan pembelajaran dalam rangka mengoperasionalkan tugas pendidikan gereja. ${ }^{4}$ Bagi Wycoff, pendidikan Kristen dalam konteks

\footnotetext{
${ }^{3}$ D. Campbell Wycoff, Theory and Design of Christian Education Curriculum (Philadelphia: The Wesmister Press, 1961), 18.

${ }^{4}$ Wycoff, Theory and Design of Christian Education Curriculum, 17. "A Curriculum is a plan by which the teaching and learning process may be systematically undertaken."
} 
gereja bertujuan membawa warga mengalami pembaharuan hidup dalam Yesus Kristus, oleh bimbingan Roh Kudus. ${ }^{5}$

Dalam rangka mengaktualkan tujuan pendidikan Kristen, Wycoff memandang bahwa kurikulum pelayanan di gereja tidak berdiri sendiri, melainkan melibatkan berbagai aspek yaitu: ${ }^{6}$

Pertama, dibutuhkan kejelasan tentang tujuan kegiatan pembelajaran di jemaat itu sendiri, untuk apa atau mengapa. Kedua, dibutuhkan gereja yang benar-benar berdasar kepada Yesus Kristus. Ketiga, membutuhkan rumah tangga yang dibangun secara Kristen. Keempat, dibutuhkan sekolah Kristen yang dibangun oleh gereja atau dasar firman Tuhan. Kelima, dibutuhkan bahan pengajaran yang benar sesuai firman Tuhan. Keenam, dibutuhkan komunitas yang menjadi konteks dan pelaksana pendidikan. Ketujuh, dibutuhkan wadah dan perlengkapan belajar. Kedelapan, dibutuhkan administrasi yang berdedikasi untuk melaksanakan tugas pembelajaran dan pendidikan.

\section{Konsep Pembinaan Warga Gereja}

Pentingnya pendidikan atau pembinaan warga gereja dapat kita lihat dari pengajaran Alkitab. Sudah seharusnya pula Alkitab menjadi pedoman bagi kita di dalam memikirkan, merencanakan dan mengelola program-program pengajaran. Sebab segala tulisan dalam Alkitab diilhamkan oleh Allah (Yunani: theopneustos; Good-breathed) sehingga tentunya berguna untuk mengajar, menyatakan kesalahan, memperbaiki kelakuan dan mendidik orang dalam kebenaran. ${ }^{7}$

\section{Hakikat Pembinaan Warga Gereja}

Dari tinjauan peristilahan, pembinaan (Inggris: nurture) mempunyai arti "memberikan makan" (to feed), memperkaya (to

\footnotetext{
${ }^{5}$ Wycoff, 25. "The climax, the very heart, of education is Christian education. Christian education seeks not just the useful life or the life of wisdom and dedication, but the reclaimed life, the transformed by the God who created man in his own image, who revealed himself with redemptive clarity in Jesus Christ, and whose Holy Spirit guides those who see and respond."

${ }^{6}$ Ibid., 25-27. Terkait dengan tugas pembinaan warga jemaat di gereja, supaya pengajaran terarah dan optimal, maka gereja membutuhkan kurikulum.

${ }^{7}$ B. S. Sidjabat, Diktat Kuliah "Teori Pendidikan Kristen" (Bandung: Sekolah Tinggi Alkitab Tiranus, Primo 2008), 30. Bandingkan 2 Timotius 3:16, 17.
} 
nourish), membesarkan (to bring up), melatih (to train) dan mendidik (to educate)." Istilah pembinaan ini dapat pula diartikan sebagai "proses, perbuatan, cara membina; pembaharuan, penyempurnaan; usaha, tindakan dan kegiatan dilakukan secara berdaya guna untuk memperoleh hasil yang lebih baik."

Dalam konteks gereja pembinaan warga jemaat seharusnya berlangsung melalui empat jalur "urat nadi" gereja, yaitu: ibadah, persekutuan, pengajaran, dan pelayanan. Namun dalam praktiknya, pengajaran dalam konteks gereja masih sering diartikan pada program sekolah minggu anak-anak, katekisasi bagi calon baptisan serta bagi para remaja atau kaum muda yang hendak disidi. Sementara dalam terang ajaran Alkitab, semua kegiatan pelayanan di gereja seharusnya terencana, terarah untuk membimbing warga jemaat mengalami kegiatan belajar?

Pada intinya, menurut pengamatan penulis, hakikat pembinaan warga gereja itu sendiri secara sederhana dapat dipahami dari dua hal ini: Pertama, berdasarkan perintah langsung dari Tuhan Yesus dalam keempat Injil. Di dalam keempat Injil terdapat sebanyak delapan puluh sembilan kali mengacu pada Yesus sebagai seorang guru; sementara mengacu pada Dia sebagai seorang pengkhotbah hanya dua belas kali. Pengajaran selalu menjadi bagian yang sentral di dalam segala hal yang Yesus lakukan. Yesus sendiri mengharapkan bahwa gereja-Nya harus menjadi gereja pengajaran sebagaimana yang terdapat dalam Amanat Agung dalam Matius 28:18-20: “..., dan ajarlah mereka melakukan segala sesuatu seperti yang telah Kuperintahkan kepadamu ..." Setiap bagian dari panggilan itu orientasnya adalah program pengajaran dan pelatihan. Oleh sebab itu, setiap kali gereja mengkhotbahkan pesan Allah yang bersifat menebus, juga di waktu yang sama gereja harus mengajarkannya. Wahyu dan pendidikan tidak dapat dipisahkan. Mengajar Injil adalah satu cara penting untuk penyebarannya. Hal ini yang memaksa alasan mengapa gereja-gereja harus mengajar tiap-tiap anggota jemaatnya.

Kedua, teladan jemaat yang mula-mula dalam Kisah Para Rasul 2:42-47. Sejak mulai berdirinya gereja pada hari pentakosta, jemaat Kristen menjunjung sekali pengajaran. Mereka segera

\footnotetext{
${ }^{8}$ B. S. Sidjabat, Diktat Kuliah “Teori Pendidikan Kristen”, 22-23.

${ }^{9}$ Ibid, 21.
} 
mengembangkan perkumpulannya dengan mengisinya dengan doa, bertekun dalam pengajaran rasul-rasul dan perbuatan-perbuatan kasih seperti yang dikehendaki Tuhan Yesus Kristus, mereka makan sehidangan dan merayakan perjamuan suci (ayat 42). Mereka mulai berkhotbah supaya banyak orang lain percaya pada Yesus Kristus sebagai Penebus dan Tuhan. Dan mereka yang bertobat dan mau bergabung dengan jemaat Kristen itu, dididik dengan saksama. Mereka belajar tentang Diri dan pekerjaan Juruselamat, dan juga tentang panggilan dan tugas seorang Kristen di dunia ini.

\section{Tujuan Pembinaan Warga Gereja}

Rumusan tujuan pembinaan warga gereja sangat beragam. Masing-masing pendidik menentukan tujuannya sendiri-sendiri, tergantung pada perspektif teologis yang dianutnya. Hal itu wajarwajar saja. Yang jelas bahwa tujuan dari suatu usaha adalah sangat penting, termasuk tujuan dari pembinaan warga gereja itu sendiri.

Pada umunya setiap tujuan mengandung tiga aspek, yaitu: aims, goals, dan objectives. Aims adalah tujuan yang diusahakan untuk dicapai pada akhirnya (secara mutlak), atau lebih tepat disebut ultimate aims (tujuan akhir). Goals adalah tujuan yang hendak dicapai dalam jangka waktu tertentu. Dan objectives adalah tujuan yang hendak dicapai dalam suatu proses belajar-mengajar. Dari ketiga aspek tersebut, tujuan yang hendak dipaparkan dalam bagian ini adalah aims atau ultimate aims.

Secara umum, tujuan-tujuan pendidikan Kristen berkembang dari penegasan tentang Allah yang diperkenalkan melalui Kristus dalam Alkitab. Pekerjaan asuhan Kristen adalah menjelaskan kabar baik tentang kasih Allah di dalam Kristus ini dalam cara begitu rupa, sehingga mereka yang lahir di dalam iman ini akan mengenalnya dalam hidup mereka sendiri, dan mereka yang menjawab dalam iman dapat memahaminya. Maksud asuhan Kristen adalah menolong orang dalam hubungan mereka yang berkembang dengan Allah di dalam Kristus sehingga mereka hidup dan memuliakan Dia serta secara efektif melayani orang lain, dalam jaminan bahwa mereka ikut serta dalam kehidupan kekal kini dan selamanya. ${ }^{10}$

\footnotetext{
${ }^{10}$ Iris V. Cully, The Bible In Christian Education (Augsburg: Fortress Publisher, 2006), 16-17.
} 
Lawrence O. Richards mengemukakan bahwa tujuan pembinaan warga gereja hanya dapat dipahami jika terlebih dahulu kita memahami tujuan gereja. Dari dasar pemikirannya tentang natur gereja sebagai organism yang hidup. ${ }^{11}$ Menurut Richards pendidikan Kristen seharusnya bukan hanya bertujuan untuk sekadar memiliki penguasaan pengetahuan atau kebiasaan tertentu. Sebagaimana halnya tujuan gereja adalah mencapai keserupaan dengan Kristus, pendidikan Kristen juga hendaknya diarahkan bagi pencapaian transformasi secara progresif sehingga keserupaan dengan Allah dalam hal sifat, nilai, motif, sikap serta pemahaman bisa terwujud. Pendidikan Kristen seharusnya dirancang untuk membantu proses tersebut berjalan dengan normal dan tidak terkesan dipaksa-paksa. ${ }^{12}$

Robert W. Pazmino sendiri melihat tujuan pembinaan di gereja erat kaitannya dengan lima tugas utama gereja, yaitu: proclamation (kerygma), community formation (koinonia), service (diakonia), advocacy (prophetia), dan worship (liturgia). ${ }^{13}$ Menurutnya pembicaraan yang tanpa menyinggung sama sekali hubungan pendidikan Kristen dengan tugas gereja hanyalah merupakan pengalaman intelektual saja. Dengan mengaitkan hubungan antara tugas gereja dengan tujuan pendidikan Kristen, Pazmino mengemukakan tugas pendidikan Kristen bertujuan untuk menyampaikan kebenaran Kristen dan mengaitkannya dengan kehidupan orang percaya. ${ }^{14}$ Dalam hal ini Pazmino memadukan tujuan pendidikan Kristen dari aspek pengetahuan Alkitab tentang Yesus Kristus dan aspek pengalaman Kristen bersama dengan Yesus Kristus.

Sedangkan bagi Andar Ismail, tujuan pembinaan jemaat adalah untuk memperlengkapi orang-orang kudus bagi pekerjaan pelayanan,

\footnotetext{
${ }^{11}$ Menurutnya hidup yang ada pada gereja adalah merupakan benih ilahi sebagaimana yang disampaikan Rasul Petrus dalam l Petrus 1:23, "karena kamu dilahirkan kembali bukan dari benih yang fana, tetapi dari benih yang tidak fana, oleh firman Allah, yang hidup dan yang kekal". Benih ilahi ini adalah milik Allah yang diterima gereja dalam Kristus melalui iman. Rancangan Allah menaruh benih ilahi-Nya dalam gereja adalah supaya gereja itu bertumbuh menjadi serupa dengan Dia. Lihat Lawrence O. Richards, A Theology of Christian Education (New York: Mc Graw Hill Book Company, 1975), 21.

${ }^{12}$ Lawrence O. Richards, A Theology of Christian Education (New York: Mc Graw Hill Book Company, 1975), 22.

${ }^{13}$ Robert W. Pazmino, God Our Teacher (Grand Rapids, Michigan: Baker Academic, 1992), 114.

${ }^{14}$ Pazmino, God Our Teacher, 44.
} 
bagi pembangunan tubuh Kristus (Efesus 4:12) - membelajarkan orang dewasa seumur hidup sesuai dengan kepenuhan Kristus (Efesus 4:13). Pembinaan warga jemaat dilaksanakan agar setiap orang dewasa menjadi bagian yang integral dalam seluruh tubuh yang rapi tersusun dan diikat menjadi satu oleh pelayanan bagiannya, sesuai dengan kadar pekerjaan tiap-tiap anggota menerima pertumbuhannya dan membangun dirinya dalam kasih (Ef. 4:16). ${ }^{15}$

Menurut Michael Harton, dalam merencanakan perumusan pembinaan di jemaat, yang adalah orang dewasa, maka kita harus memulainya dari penilaian terhadap kebutuhan orang dewasa itu sendiri. Untuk itu sangat penting mengkonsultasikan kebutuhan orang dewasa dengan berbagai sumber informasi yaitu memperkaya pengertian kita dengan literatur tentang tugas dan pengembangan orang dewasa dan dengan bertanya langsung kepada orang dewasa itu. $^{16}$

\section{Isi Pengajaran dalam Pembinaan Warga Gereja}

Secara teologis panggilan gereja yang sering kita kenal antara lain ialah beribadah (liturgia), bersekutu (koinonia), pemberitaan (kerygma), mengajar (didache), melayani (diakonia), meneguhkan (profeteia), bersaksi (marturia). Supaya terarah dan optimal, maka gereja membutuhkan kurikulum. Supaya program dan kegiatan gereja berlangsung dengan baik, maka ia membutuhkan kurikulum. Kurikulum yang dimaksud bukan hanya pengajaran, tetapi juga tujuan dan pengalaman belajar yang dialami mereka yang mengikuti kegiatan.

Dalam menyusun kurikulum gereja, menurut Colson dan Rigdon, Alkitab memiliki beberapa sifat dasar sehingga menjadi falsafah bagi pengembangan kurikulum. Alkitab adalah wahyu Allah sebagai sarana untuk memperkenalkan diri-Nya kepada manusia. Alkitab

\footnotetext{
${ }^{15}$ Andar Ismail, Selamat Natal - 33 Renungan tentang Natal (Jakarta: BPK Gunung Mulia, 1997), 765. Dari penjelasan tersebut di atas, penulis sendiri melihat tujuan yang umum pembinaan warga gereja, tidak lebih dari usaha pendidikan di dalam gereja yaitu untuk menolong anggota-anggota gereja bertumbuh menuju kedewasaan iman di dalam pribadi dan karya Yesus Kristus, yang dapat mengenal kebenaran dan menghindari kesalahan.

${ }^{16}$ Michael Harton, "Program Planning Models for Adult Christian Education" dalam A Church Ministering to Adults (ed. Jerry M. Stubblefield). (Nashville: Broadman Press. 1986), 145-146.
} 
sebagai sumber ajaran kristiani, norma untuk pendidikan Kristen, alat yang menghidupkan dalam pendidikan Kristen karena Roh Kudus memakainya untuk membawa orang semakin mengenal Allah dalam komunitas warga jemaat. Alkitab memberitakan keselamatan bagi dunia melalui berita Injil. Itu sebabnya Allah mengilhami Alkitab untuk mengubah kehidupan seseorang. Allah menyatakan pemeliharaan-Nya kepada umat percaya melalui Alkitab. Alkitab adalah hadiah Allah yang menuntun orang kepada keselamatan. Alkitab menjadi pedoman bagi hidup orang percaya. Alkitab membawa seseorang mengenal Yesus sebagai Tuhan dan Juruselamat. ${ }^{17}$

Colson dan Rigdon mengemukakan bahwa dalam menyusun kurikulum pendidikan konteks gereja, titik tolak harus dari tujuan (objectives). Apa yang menjadi tujuan pendidikan Kristen konteks gereja? Bertolak dari tujuan itu, pertanyaan: Apa yang harus menjadi isi kurikulum? Bahan kajian (subject matter) haruslah terkait dengan pengalaman hidup (related to experience). Dari tujuan, kita membahas masalah cakupan atau scope yang maksudnya lebih luas dari sekedar muatan (content). Ruang lingkup harus dilihat dari kacamata Injil, yang membahas pengalaman hidup Kristen dalam hubungan dengan Allah, dalam hubungan dengan sesama dan dalam hubungan dengan dunia. Selanjutnya, menurut Colson dan Rigdon, ruang lingkup kurikulum meliputi lima tema penting, yaitu: Pertama, setting kehidupan: relevansi manusia. Manusia dengan dirinya; manusia dengan sesama; manusia dengan perubahan; manusia dengan masyarakat (nilai, adat, agama lain, dll). Kedua, relevansi penyataan Allah dan penyataan penebusan. Allah berbicara/menyapa manusia; Allah mencari/menyelamatkan manusia; Allah yang murah hati, menghakimi dan menebus; Allah yang hadir dalam hidup manusiaYesus Kristus; Alkitab komunikasi Allah kepada manusia-Roh Kudus; Allah berbicara kepada manusia melalui gereja; Allah berbicara kepada manusia melalui alam. Ketiga, hidup sebagai anakanak Tuhan: bagaimana kita sebagai anak-anak Tuhan yang sudah ditebus Allah. Kasih Allah yang menebus; respon kita terhadap penebusan; menjadi manusia baru dalam Yesus; bertumbuh di dalam

\footnotetext{
${ }^{17}$ Colson, Howard P., Raymond M. Rigdon. Understanding Your Church's Curriculum (Nashville, Tenesse: Baptist Sunday School Board, 1981), 105-106.
} 
Yesus; identitas Kristen dalam komunitas (siapa saya?); pengharapan Kristen dalam kekuatan Allah (mengalami mujizat Allah). Keempat, panggilan hidup murid Yesus (etika): panggilan Allah- pengambilan keputusan. Panggilan untuk melayani sesama; tanggung jawab hidup dan kerja; disiplin kehidupan Kristen; tugas pemuridan dunia; kerajaan Allah. Kelima, hidup bergereja: kasih Allah menyatukan/mengikat. Perbuatan Allah di dalam dan melalui umat; gereja memengaruhi masyarakat; pelayanan pendamaian dan penebusan; hidup gereja yang beribadah/yang menyembah; gereja yang bermisi; gereja yang melayani. ${ }^{18}$

\section{Konsep Kurikulum Dalam Pembinaan Warga Gereja}

Kurikulum dapat diartikan sebagai rencana kegiatan belajar yang ditempuh peserta didik untuk mencapai tujuan tertentu. Istilah ini berasal dari kata curere (Latin), yang berarti pacuan kuda, ada garis awal dan ada tujuan serta garis akhir, lintasan yang ditempuh pelari dalam pertandingan, dari awal hingga akhir. Dalam konteks sekolah, kurikulum berarti keseluruhan kegiatan belajar yang ditempuh anak didik oleh bimbingan peserta didik, guna mencapai tujuan yang ditetapkan. Tujuan ini luas cakupannya dan termasuk peningkatan pengetahuan, perubahan sikap, pengembangan keterampilan..$^{19}$

Chester O. Gallowey mengemukakan bahwa konsep kurikulum seseorang dipengaruhi oleh filsafat pendidikan, ajaran teologi, pemahaman psikologis dan sosiologisnya, dan oleh warisan historisnya. ${ }^{20}$ Dengan demikian, ada beragam definisi tentang kurikulum, yang dapat kita temukan dalam ahli-ahli pendidikan baik secara umum maupun secara khusus dalam konteks gereja.

Jika kita berbicara mengenai kurikulum, maka ada beberapa istilah yang terkait di dalamnya. Pertama, kurikulum ideal, atau kurikulum tertulis, dalam bentuk rancangan atau pedoman kurikulum. Biasanya memuat tema-tema atau pokok bahasan, tujuan,

\footnotetext{
${ }^{18}$ Colson dan Ridgon, Understanding Your Church's Curriculum, 46-48.

${ }^{19}$ S. Nasution, Kurikulum dan Pengajaran (Jakarta: Bumi Aksara, 1989), 9-10

${ }^{20}$ Chester O. Gallowey, Exploring Christian Education (Kansas City: Beacon Hill Press, 1978), 162.
} 
sumber belajar, rancangan detail bahan pengajaran, usulan metode, alokasi waktu dan susunan (organisasi).

Kedua, kurikulum yang nyata di dalam interaksi belajar atau kegiatan sekolah ataupun gereja. Bentuk kurikulum ini dimulai dari desain pembelajaran yang memuat tujuan instruksional, topik-topik yang akan dipelajari, sumber belajar dan media, langkah-langkah kegiatan belajar-kegiatan awal, kegiatan inti dan kegiatan penutup, selanjutnya diakhiri dengan evaluasi dan penugasan. Atas dasar rancangan itu, guru atau pengajar mengelola kegiatan belajar bersama peserta didiknya.

Ketiga, Kurikulum terselubung (hidden curriculum), terkait dengan apa yang muncul dalam kegiatan belajar namun tidak tertulis dalam pedoman kurikulum maupun dalam pedoman pembelajaran (instruksional). Nasution mengemukakan hal-hal yang terkait dengan hidden curriculum ini sebagai berikut: "Murid-murid mempunyai aturan-aturan sendiri sebagai reaksi terhadap kurikulum yang formal seperti tentang menyontek, membuat pekerjaan rumah, menjadi juara kelas, sikap terhadap guru, dan sebagainya." ${ }^{21}$

Mengutip gagasan Elizabeth Vallence, Pazmino mengemukakan tiga ciri khas hidden curriculum, yaitu: ${ }^{22}$

1. Apa saja yang terkait dengan konteks pendidikan termasuk interaksi guru dengan murid, struktur ruangan kelas, keseluruhan pola-pola organisasi sebagai mikrokosmos dari sistem nilai masyarakat.

2. Dapat tampak dalam sejumlah proses yang berlangsung di gereja, di sekolah, di rumah, termasuk penanaman nilai, sosialisasi, dan pemeliharaan struktur sosial.

3. Dapat mencakup hal-hal yang tersembunyi dan mengemuka mulai dari penyusunan kurikulum hingga ke hasil belajar yang ditunjukkan di dalam kehidupan masyarakat.

Tentang hidden curriculum ini lebih jauh Pazmino mengemukakan:

By contrast, the implicit or hidden curriculum includes the sociological psychological dimensions of education, which are usually caught rather than intentionally taught.

\footnotetext{
${ }^{21}$ S. Nasution, Pengembangan Kurikulum (Bandung: Citra Aditya Bhakti, 1989), 11.

${ }^{22}$ Robert W. Pazmino, Foundation Issues in Christian Education (Grand Rapids, Michigan: Baker Book House, 1997), 236-237.
} 
Aspect of the hidden curriculum include the nature of behaviors fostered, compliant or initiative; the type of relationship modeled, competitive or cooperative; and the values emphasized in the community, such as the Christian values of faith, hope, love, truth, peace, joy, and justice. ${ }^{23}$

Jadi, dalam merancang kurikulum kita tidak hanya harus memikirkan apa yang mestinya tertulis di kertas, tetapi juga apa yang akan terjadi di dalam proses interaksi guru dengan murid. Harus ada antisipasi ke depan, mengenai apa yang terjadi di dalam kegiatan pembelajaran jika kurikulum diaplikasikan. Ada kemungkinan bahwa mereka yang belajar lebih banyak mendapat masukan pengetahuan, sikap dan nilai bahkan keterampilan dari hal-hal yang dilakukan pengajar di depan atau bersama peserta didik, yang semuanya tidak ada pada pedoman belajar atau silabus.

\section{Komponen Kurikulum}

Untuk menerangkan apa itu kurikulum kita dapat meniliknya dari unsur-unsur atau komponen yang terkandung di dalamnya. Secara ringkas, para ahli mengemukakan bahwa kurikulum dapat dipahami pula dari unsur-unsur ataupun komponennya. Nasution mengemukakan ada empat komponen utama kurikulum, yakni: ${ }^{24}$

a) Tujuan

b) Bahan pengajaran

c) Metode, strategi, alat dan media pembelajaran

d) Evaluasi keberhasilan

Keempat komponen ini dapat kita jadikan sebagai pedoman ketika merencanakan kurikulum.

Sukmadinata mengemukakan enam komponen utama kurikulum: ${ }^{25}$ (1) Tujuan, yang mengarahkan kegiatan pengajaran dan akan mewarnai komponen lainnya. Tujuan ini dirumuskan dari kebutuhan masyarakat dan peserta didik serta berdasarkan pertimbangan filosofis. (2) Bahan ajar, apa yang dipelajari peserta didik dalam interaksi dengan guru/pengajar. Dalam mempertimbangkan bahan ajar (isi), harus diperhatikan aspek

\footnotetext{
${ }^{23}$ Robert W. Pazmino, Principles and Practices of Christian Education (Grand Rapids, Michigan: Baker Book House, 1992), 93.

${ }^{24}$ S. Nasution, Kurikulum dan Pengajaran (Jakarta: Bumi Aksara, 1989), 5.

${ }^{25}$ Nana Syaodih Sukmadinata, Pengembangan Kurikulum: Teori dan Praktek. (Bandung: Rosda Karya, 1997), 102-112.
} 
urutannya (sekuens) baik secara kronologis, struktural, logis dan psikologis, spiran dan hirarki belajar. (3) Strategi mengajar, terdiri dari tiga jenis: a) reception/eksposition learning-discovery learning; b) rote learning, meaningful learning; c) group learning-individual learning. (4) Media mengajar; interaksi insane, realia, pictorial, simbol tertulis dan rekaman suara. (5) Evaluasi pengajaran: evaluasi hasil belajar dan evaluasi pelaksanaan pengajaran. (6) Penyempurnaan pengajaran (remedial).

Menurut Pazmino, ketika merencanakan sebuah kurikulum kita dapat pula mengajukan pertanyaan-pertanyaan penuntun sebagai berikut: ${ }^{26}$

1. Apa saja yang harus dipelajari oleh peserta didik di dalam kegiatan belajar? Bidang pengetahuankah? Bidang afektif, sikap dan nilai hidupkah? Masalah keterampilankah?

2. Untuk apa semua hal itu dipelajari? Apa tujuan jangka pendek maupun tujuan jangka panjangnya? Perubahan hidup apa yang akan dialami mereka yang mempelajarinya?

3. Dimana kegiatan belajar berlangsung? Dalam konteks ibadah di gerejakah? Dalam konteks katekisasikah? Dalam konteks persekutuan rumah tanggakah? Dalam kegiatan rekreasi di tepi pantaikah?

4. Siapa yang mengikuti kegiatan belajar itu? Cocokkah bahan-bahan yang dipelajari dengan tingkat perkembangan mereka?

5. Kapankah kegiatan belajar dilakukan? Apakah sebuah aspek yang dipelajari cocok diajarkan sekarang atau nanti saja mencari waktu yang tepat?

6. Dengan cara bagaimana tujuan belajar secara efektif dicapai? Strategi apa? Media apa yang diperlukan?

Sejalan dengan yang diusulkan Pazmino di atas D. Campbell Wycoff juga mengemukakan bahwa di dalam memahami pengembangan kurikulum pendidikan Kristen konteks gereja, berarti kita didesak untuk selalu memikirkan jawaban dari enam pertanyaan mendasar, yaitu:

Where is the curriculum? What is the locus of the curriculum of the Christian education? Where does Christian education's communicative

\footnotetext{
${ }^{26}$ Pazmino, Principles and Practices of Christian Education, 226-227.
} 
transaction really take place? This is the question of the context of Christian education. What is the curriculum? What is the curriculum's substance? What does it have to communicate? This question of the scope of Christian education and its curriculum. Why is the curriculum? What it is objective? This is the question of the purpose of Christian education and its curriculum. How is the curriculum? How does the communicative transaction take place in Christian education? What is the clue to process and method? This is the question of the process of Christian education and its curriculum. In what ways shall the curriculum be organized? How shall all patient factors be taken into account, weighed, and related to one another in such a way that the practicalities of a curriculum organized for use may be archived? This is the question of the organizing principle of the curriculum. By what means shall the curriculum be organized? What instrumentalities are available, in hamony with the organizing principle, by which the curriculum may be worked out in practice? This is the question of organizing medium for the curriculum. ${ }^{27}$

\section{Peran dan Fungsi Kurikulum}

Mengacu kepada pendapat Sanjaya Oemar Hamalik mengemukakan tiga peran penting kurikulum yaitu: ${ }^{28}$

Pertama, peran konservatif, yakni melestarikan warisan nilai-nilai hidup yang dianggap baik oleh masyarakat. Kedua, peran kreatif, yaitu mampu menciptakan hal-hal baru untuk peningkatan potensi peserta didik. Ketiga, peran kritis dan evaluatif, yakni mampu memberikan respon dan penilaian terhadap nilai-nilai yang dianggap tidak sesuai dengan masyarakat.

Betapa pentingnya kurikulum pelayanan PAK di sekolah atau kurikulum Pembinaan Warga Gereja (PWG) di jemaat lokal kita rumuskan dan kembangkan? Untuk itu kita harus memiliki pemahaman tentang perannya. Kita dan kawan-kawan harus memahami apa makna dan fungsi kurikulum. Bagaimana kita melukiskan signifikansi atau kegunaan kurikulum? Sebagai apa kurikulum dapat kita gambarkan? Ada berbagai macam fungsi kurikulum.

${ }^{27}$ Wycoff, Theory and Design of Christian Education Curriculum, 84.

${ }^{28}$ Sanjaya Oemar Hamalik, Proses Belajar Mengajar (Jakarta: Bumi Aksara, 2008), $10-11$. 
1) Sebagai alat untuk mengembangkan kemampuan berpikir dari mereka yang menggunakannya. Dalam kaitan itu tentunya harus ada pengetahuan atau pemahaman yang dipelajari.

2) Sebagai aktualisasi diri. Melalui kurikulum pendidik dan peserta didik mengalami pembentukan pribadi bahkan menemukan makna dan potensi dirinya. Kalau kurikulum sebagai pemenuhan kebutuhan manusia, maka dalam perencanaannya ia harus bertolak dari pemahaman siapa manusia.

3) Sebagai teknologi pembelajaran, yakni memuat atau membicarakan bagaimana merencanakan, mengelola dan melaksanakan kegiatan belajar. Kurikulum berfungsi sebagai alat atau sarana dalam the how to. Kurikulum sebagai teknologi juga memikirkan bagaimana membentuk kompetensi dalam bentuk perilaku objektif peserta didik. Kalau kurikulum sebagai teknologi, berarti ia tidak lepas dari alat-alat teknologi (pendidikan), perangkat lunak dan perangkat keras, di dalam realisasinya.

4) Sebagai rekonstruksi masyarakat maupun gereja. Dengan adanya kurikulum sekolah yang disusun dengan baik, diharapkan para lulusan mampu membawa pembaruan dalam masyarakat. Begitu juga dengan kurikulum pelayanan jemaat, ia diharapkan mampu membawa pembaruan bagi kehidupan warga jemaat itu sendiri. Kurikulum yang dikembangkan oleh sebuah gereja akan membangun identitasnya sendiri.

5) Sebagai pemelihara pengetahuan dan ajaran. Kalau gereja hendak memperlengkapi warganya bertumbuh dalam ajaran yang baik dan benar, maka harus disusun kurikulum. Kurikulum itu tentunya memuat apa saja yang mesti dipahami oleh orang Kristen. Kurikulum sebuah gereja atau denominasi memperlihatkan keyakinan iman kognitif, afektif, konatif, social dari gereja /denominasi itu sendiri.

6) Sebagai pengembangan watak, karakter, moral, dan iman. Kalau watak jemaat hendak berubah dengan baik, maka dibutuhkan kurikulum yang sesuai dengan tujuan itu. Kurikulum PAK di sekolah (2003) misalnya, sarat dengan muatan nilai-nilai kehidupan (etis). Tidak berlebihan jika kurikulum PAK di sekolah lebih fokus kepada teknologi pembentukan kompetensi anak didik.

7) Sebagai alat untuk lebih mengenal dan memuliakan Allah. Keseluruhan aktivitas, interaksi dalam kurikukum menciptakan sarana mempermuliakan Allah. Bukankah dalam segala sesuatu yang 
kita rencanakan dan kerjakan nama Tuhan harus dipermuliakan? (band. 1 Korintus 10:31; Kolose 3:17, 23). Rencana kurikulum yang disosialisasikan kepada warga jemaat akan membantu mereka mengetahui bagaimana gereja secara keseluruhan hidup beribadah dan melayani.

\section{Desain Kurikulum Dalam Pembinaan Warga Gereja}

Desain kurikulum dapat diartikan sebagai kerangka, pola, bagaimana kurikulum dirancang dan dikembangkan atau diorganisasikan. Menurut Nasution, "dalam organisasi atau desain kurikulum, dicoba diwujudkan apa yang diketahui tentang teori, konsep, pandangan tentang pendidikan, perkembangan anak dan kebutuhan masyarakat. Kurikulum itu menentukan apa yang akan dipelajari, kapan waktu yang tepat untuk mempelajarinya, keseimbangan bahan pelajaran dan keseimbangan antar aspek-aspek pendidikan yang akan disampaikan." ${ }^{29}$

Dengan meminjam gagasan Syaodih Sukmadinata, desain kurikulum dapat diterapkan sebagai berikut:

Desain kurikulum merupakan suatu pengorganisasian tujuan, isi, serta proses belajar yang akan diikuti siswa pada berbagai tahap perkembangan pendidikan. Dalam desain kurikulum, ada dua dimensi penting, yaitu: (l) subtansi, unsur-unsur serta organisasi dari dokumen tertulis kurikulum; (2) model pengorganisasian dan bagian-bagian kurikulum terutama organisasi dan proses pengajaran., ${ }^{30}$

Dalam kaitan dengan pendidikan teologi, LeRoy Ford sebagaimana dikutip B. S. Sidjabat, mengemukakan pengertian dan fungsi, fokus serta bagaimana mengembangkan desain kurikulum sebagai berikut:

(a) Desain kurikulum yang berada dalam dokumen yang sudah didokumentasikan dapat diadopsi, ditolak, atau dimodifikasi.

(b) Desain kurikulum dapat rancang dari fondasi teologi, filsafat, sosiologi, seni komunikasi dan antropologi. Teologi berfungsi sebagai penafsir dari bidang-bidang keilmuan yang lain.

\footnotetext{
${ }^{29}$ Nasution, Pengembangan Kurikulum, 106.

${ }^{30}$ Nana Syaodih Sukmadinata, Pengembangan Kurikulum: Teori dan Praktek. (Bandung: Rosda Karya, 1997), 34.
} 
(c) Desain kurikulum mencerminkan fokus, seperti hasil pembelajaran, isu-isu sosial, pembelajaran umum, pembelajaran interdisipliner, disiplin klasik, atau kombinasi-kombinasinya. ${ }^{31}$

\section{Model-model Desain Kurikulum}

Kalau kita hendak mendesain sebuah kurikulum, hal itu berkaitan erat dengan tujuan pendidikan yang hendak kita capai. Berbeda dengan tujuan, berbeda pula desain kurikulumnya. Untuk lebih jelasnya memahami arti desain kurikulum, dapat kita simak pandangan Nasution sebagai berikut:

Seperti halnya dengan sebuah gedung misalnya, desain itu akan berbeda-beda menurut tujuan gedung itu, apakah untuk sekolah, gudang, toko atau tempat tinggal, demikian pula ada perbedaan desain kurikulum yang bertalian dengan tujuan yang diutamakan, apakah penguasaan kebudayaan dan pengetahuan umat manusia, ataukah masyarakat atau anak. Bila tujuannya terutama transmisi atau penyampaian kebudayaan dan pengetahuan maka yang paling sesuai ialah organisasi kurikulum berupa mata pelajaran yang lazim disebut subject curriculum. ${ }^{32}$

Dalam tulisannya, Pengembangan Kurikulum, Nana S. Sukmadinata mengemukakan tiga model desain kurikulum. Pertama, subject centered design, suatu desain yang berpusat pada bahan ajar. Ragamnya termasuk subject design, discipline design dan broadfields design (bersifat integratif); Kedua, leaner centered design, suatu kurikulum yang mengutamakan peranan dan kebutuhan siswa. Kurikulum itu dapat dirancang berdasarkan pengalaman, minat dan aktivitas berkenaan dengan kebutuhan siswa; Ketiga, problem centered design, desain kurikulum yang berpusat kepada masalah-masalah yang dihadapi siswa di masyarakat. Kurikulum ini dapat dirumuskan berdasarkan lingkup atau area kehidupan (areas living design), atau berdasarkan pokok-pokok khusus (core design). ${ }^{33}$

Untuk lebih jelasnya, marilah kita simak gagasan Saylor \& Alexander yang mengemukakan lima model desain kurikulum yang

\footnotetext{
${ }^{31}$ B. S. Sidjabat, Makalah "Desain Kurikulum” (Cihanjuang: Sekolah Tinggi Alkitab Tiranus, 2008), 2.

${ }^{32}$ Nasution, Kurikulum dan Pengajaran, 106.

${ }^{33}$ Sukmadinata, Pengembangan Kurikulum: Teori dan Praktek, 113-124.
} 
lazim berkembang dalam konteks pendidikan formal, yang diringkaskan sebagai berikut: ${ }^{34}$

Tabel 1. Tabel Lima Model Desain Kurikulum dalam Konteks Pendidikan Formal

\begin{tabular}{|c|c|c|}
\hline $\begin{array}{l}\text { Curriculum Design } \\
\text { (Desain Kurikulum) }\end{array}$ & $\begin{array}{l}\text { Primary Source of Data } \\
\text { for Goals and Objectives } \\
\text { (Sumber Utama Data } \\
\text { untuk Tujuan dan } \\
\text { Sasaran }\end{array}$ & $\begin{array}{l}\text { Usual Ways to Organize } \\
\text { Instruction } \\
\text { (Cara untuk Mengatur } \\
\text { Instruksi) }\end{array}$ \\
\hline $\begin{array}{l}\text { 1. Subject } \\
\text { matter/disciplines } \\
\text { (materi pokok/disiplin) } \\
\text { 2. Specific } \\
\text { competency/tecnology } \\
\text { (Spesifik } \\
\text { kompetensi/teknologi } \\
\text { 3. Human traits/process } \\
\text { (Sifat/karakteristik } \\
\text { peserta/proses) } \\
\text { 4. Social } \\
\text { functions/activities } \\
\text { (Fungsi } \\
\text { sosial/aktivitas) } \\
\text { 5. Individual needs and } \\
\text { interests/activities } \\
\text { (Kebutuhan \& } \\
\text { kepentingan } \\
\text { individual/kegiatan) }\end{array}$ & $\begin{array}{l}\text { 1. Subject matter to be } \\
\text { learned (Subyek untuk } \\
\text { dipelajari) } \\
\text { 2. Competencies to be } \\
\text { acquired (Kompetensi } \\
\text { yang akan diperoleh) } \\
\text { 3. Human traits of } \\
\text { learners to be developed } \\
\text { (Sifat manusia sebagai } \\
\text { pelajar untuk } \\
\text { dikembangkan) } \\
\text { 4. Needs of social } \\
\text { (Kebutuhan } \\
\text { masyarakat) } \\
\text { 5. Needs and interests of } \\
\text { the learners } \\
\text { (Kebutuhan dan } \\
\text { kepentingan di pelajar). }\end{array}$ & $\begin{array}{l}\text { 1. By disciplines (for example, } \\
\text { chemistry) - displin, contoh } \\
\text { Bidang Kimia. } \\
\text { 2. Through instructional design } \\
\text { (for example, learning } \\
\text { modules) - desain } \\
\text { instruksional, mis. Modul } \\
\text { pembelajaran. } \\
\text { 3. Through planned processes } \\
\text { (for example, values } \\
\text { clarification exercises) - } \\
\text { proses yang direncanakan, } \\
\text { mis. Klarifikasi nilai-nilai } \\
\text { latihan. } \\
\text { 4. Through community } \\
\text { activities or 1,2, or } 3 \text { above } \\
\text { (for example "get out the } \\
\text { vote" campaign. - Melalui } \\
\text { kegiatan-kegiatan } \\
\text { masyarakat, mis. Keluar } \\
\text { berkampanye. } \\
\text { 5. Through independent } \\
\text { learning activities or 1,2, or } 3 \\
\text { above (for example, learning } \\
\text { to paint). - melalui kegiatan } \\
\text { belajar secar mandiri, mis. } \\
\text { Belajar melukis. }\end{array}$ \\
\hline
\end{tabular}

\section{Seleksi Desain Kurikulum}

Sebagaimana dikemukakan oleh Nasution di atas, desain kurikulum yang kita pilih, atau yang kita tetapkan dan kembangkan, semuanya bergantung kepada tujuan pendidikan dan pembelajaran yang kita sadari dan rumuskan. Itu sebabnya dalam mendesain kurikulum, kejelasan rumusan tujuan menjadi amat penting dan mendasar. Tentu saja tujuan itu bertolak dari konteks pendidikan, dari kebutuhan peserta didik yang mengikuti pendidikan, juga berpedoman kepada visi dan misi lembaga pendidikan. Bertolak dari

${ }^{34}$ J. Galen Saylor, Alexander William M, dan Arthur Lewis, Curriculum Planning for Better Teaching and Learning (Japan: Holt-Saunders, 1981), 206. 
apa yang menjadi tujuan pendidikan yang kita terapkan, Saylor dan Alexander memberikan kerangka ringkas mengenai kriteria seleksi desain kurikulum sebagai berikut: ${ }^{35}$

Tabel 2. Kerangka Mengenai Kriteria Seleksi Desain Kurikulum

\begin{tabular}{|l|l|l|}
\hline \multicolumn{1}{|c|}{$\begin{array}{l}\text { If Curriculum Planners } \\
\text { Intend to: }\end{array}$} & $\begin{array}{c}\text { Consider Using } \\
\text { This } \\
\text { Design }\end{array}$ & Consider Organizing Instruction \\
\hline $\begin{array}{l}\text { Provide organized } \\
\text { knowledge, for example, } \\
\text { knowledge in the } \\
\text { biological science. }\end{array}$ & $\begin{array}{l}\text { Subjectmatter/ } \\
\text { disciplines }\end{array}$ & Around disciplines of knowledge \\
$\begin{array}{l}\text { Develop specific } \\
\text { competencies or skills, for } \\
\text { example, ability to add, } \\
\text { ability to type. }\end{array}$ & $\begin{array}{l}\text { Specific } \\
\text { competencies/te } \\
\text { chnology }\end{array}$ & $\begin{array}{l}\text { Through am instructional system } \\
\text { design based on a task analysis }\end{array}$ \\
$\begin{array}{l}\text { Develop human traits, for } \\
\text { example, knowing how to } \\
\text { learn, ability to solve } \\
\text { problems, ability to lead } \\
\text { effectively, ability to be } \\
\text { analytical about one's } \\
\text { values. }\end{array}$ & $\begin{array}{l}\text { Human } \\
\text { traits/processes }\end{array}$ & $\begin{array}{l}\text { Through planned processes involving } \\
\text { extensive experiences related to the } \\
\text { traits sought. }\end{array}$ \\
$\begin{array}{l}\text { Related education to } \\
\text { society, for example, } \\
\text { assist learners to deal } \\
\text { with persistent life } \\
\text { situations, improve the } \\
\text { local community, } \\
\text { reconstruct society. }\end{array}$ & $\begin{array}{l}\text { Social } \\
\text { functions/activi } \\
\text { ties }\end{array}$ & $\begin{array}{l}\text { Through eggaging learners in social } \\
\text { activities and extensive study of } \\
\text { social and community problems and } \\
\text { programs. }\end{array}$ \\
$\begin{array}{l}\text { example, learn to paint, } \\
\text { establish good } \\
\text { relationships with peers. }\end{array}$ & $\begin{array}{l}\text { Needs and } \\
\text { interests/activit } \\
\text { ies }\end{array}$ & $\begin{array}{l}\text { Through egaging learners as } \\
\text { individuals or in groups in activities } \\
\text { related to their needs and interests. }\end{array}$ \\
\end{tabular}

\section{Implikasi Desain Kurikulum Bagi Pembinaan Warga Gereja}

Ada beberapa gagasan yang dapat kita petik dan kembangkan dari penjelasan di atas bagi pelayanan jemaat. Kita dapat mengembangkan kurikulum pelayanan sekolah Minggu atau remaja yang berorientasi kepada pengajaran isi Alkitab, atau pengajaran

${ }^{35} \mathrm{~J}$. Galen Saylor, Alexander William M, dan Arthur Lewis, Curriculum Planning for Better Teaching and Learning, 252. 
dogma gereja (subject centered). Kemungkinan lain, kita dapat merencanakan kurikulum yang sifatnya memenuhi kebutuhan psikologis dan spiritual warga jemaat, bergantung kepada pergumulan mereka dan jawabannya dari Alkitab. Mungkin saja lagi kita merumuskan kurikulum bertolak dari tantangan budaya, masyarakat dan keagamaan. Aktivitas belajar bertujuan memampukan peserta (warga) menghadapi masyarakatnya secara kritis, konstruktif dan kreatif.

Pengembangan kurikulum pelayanan jemaat dengan pendekatan integratif dan holistik adalah tepat. Artinya, kita harus mempertimbangkan firman Tuhan (teks), termasuk dogma (warisan) gereja di masa lalu. Selain itu, kita juga mesti mempertimbangkan tingkat perkembangan warga jemaat beserta kebutuhannya. Akhirnya, isi pengajaran yang direncanakan haruslah berguna menjawab tantangan zaman di mana warga menjalankan kehidupan sehari-hari (band. 1 Petrus 3:15).

Wycoff mengusulkan bahwa kalau kita merancang sebuah kurikulum pelayanan di gereja, maka ada sejumlah aspek yang kita jelaskan dan tuliskan: ${ }^{36}$

1. Prinsip dasar kurikulum itu. Kita harus menjelaskan:

a) Konteks pendidikan dimana?

b) Skopa atau ruang lingkup pendidikan

c) Tujuan pendidikan itu apa?

d) Proses pendidikan bagaimana?

e) Prinsip organisasi bahan itu bagaimana, apa?

2. Penjelasan tugas-tugas pembelajaran, mencakup:

a) Tugas-tugas atau kegiatan belajar itu apa dan apa maksudnya?

b) Implementasinya bagi prinsip-prinsip dasar tadi.

c) Teori pembelajaran apa yang dipergunakan?

d) Penggunaan kegiatan belajar dalam kurikulum.

3. Analisis bidang cakupan kurikulum berdasarkan ruang lingkup, topik, tema.

a) Bidang cakupan firman Allah, mencakup: firman Allah, teologi, gereja itu apa? Gereja dalam dunia, gereja sekarang ini, hubungan antara manusia, perwujudan diri sendiri, kehidupan Kristen.

\footnotetext{
${ }^{36}$ Wycoff, Theory and Design of Christian Education Curriculum, 187-188.
} 
b) Bagaimana bidang-bidang itu dijabarkan lagi sesuai dengan situasi dan kebutuhan peserta didik berdasarkan kategori usia misalnya.

4. Penjelasan mengenai peserta didik.

a) Bagaimana kegiatan belajar jika sifatnya individual, metode atau teknik apa yang dipergunakan?

b) Bagaimana kegiatan belajar sebagai kelompok dalam kelompok?

c) Apa yang mungkin dijumpai dalam kegiatan belajar?

5. Diskusi tentang bagaimana proses pembelajaran dilangsungkan baik untuk individu maupun kelompok?

6. Usulan metode dan pendekatan mengajar.

7. Usulan sumber-sumber pembelajaran.

8. Usulan urutan pembelajaran, atau sekuensnya.

9. Usulan evaluasi kegiatan belajar.

Colson dan Rigdon mengusulkan bahwa dalam desain sebuah kurikulum pendidikan konteks gereja, kegiatan harus dimulai dengan memahami tugas-tugas belajar (learning teks) peserta didik. Setiap orang melakukan tugas penting, yaitu: 1) penelusuran dan penyelidikan (exploring); 2) penemuan (discovery); dan 3) penilaian dan penghayatan (appropriation); dan 4) penerapan (application). Tujuan belajar ialah membawa orang mengalami hubungan dinamis dengan Allah dalam terang Injil. Roh Kudus terlibat dalam aktivitas itu. Peserta didik menyatakan kebenaran Injil dalam kehidupannya. ${ }^{37}$

Desain menentukan langkah berikutnya. Sekarang, jika kita merencanakan kurikulum pendidikan warga jemaat, kita dapat memilih apakah: 1) Berdasarkan Alkitab dan teologi saja. Jika demikian desainnya subject matter oriented; 2) Berdasarkan kebutuhan dan pengalaman peserta didik. Dengan demikian kita memiliki desain learned oriented. Diharapkan kurikulum itu menjawab kebutuhan dan pergumulan warga jemaat; 3)Berdasarkan tugas-tugas kehidupan di masyarakat. Jika demikian desain rancangan kita adalah competency based; 4) Berdasarkan tantangan dalam kehidupan masyarakat dan bagaimana menjadi garam dan terang di dalamnya. Jika demikian desain kita bersifat society oriented.

\footnotetext{
${ }^{37}$ Colson dan Ridgon, Understanding Your Church's Curriculum, 57.
} 


\section{Kepustakaan}

Colson, Howard P., dan Raymond M. Rigdon. Understanding Your Church's Curriculum. Nashville: Broadmann Press, 1981.

Cully, Iris V. The Bible In Christian Education. Augsburg: Fortress Publisher, 2006.

Gallowey, Chester O. Exploring Christian Education. Kansas City: Beacon Hill Press, 1978.

Hamalik, Sanjaya Oemar Proses Belajar Mengajar. Jakarta: Bumi Aksara, 2008.

Ismail, Andar. Selamat Natal - 33 Renungan tentang Natal. Jakarta: BPK Gunung Mulia, 1997.

Nana Syaodih Sukmadinata, Pengembangan Kurikulum: Teori dan Praktek. Bandung: Rosda Karya, 1997.

Nasution, S. Kurikulum dan Pengajaran. Jakarta: Bumi Aksara, 1989. 1989.

Pengembangan Kurikulum. Bandung: Citra Aditya Bhakti,

Pazmino, Robert W. God Our Teacher. Grand Rapids, Michigan: Baker Academic, 1992.

Foundation Issues in Christian Education. Grand Rapids, Michigan: Baker Book House, 1997.

Principles and Practices of Christian Education. Grand Rapids, Michigan: Baker Book House, 1992.

Richards, Lawrence O. A Theology of Christian Education. New York: Mc Graw Hill Book Company, 1975.

Saylor, J. Galen, Alexander William M, dan Arthur Lewis. Curriculum Planning for Better Teaching and Learning. Japan: Holt-Saunders, 1981.

Sanjaya, Wina. Kurikulum dan Pembelajaran. Jakarta: Kencana Prenada Media Group, 2008.

Sidjabat, B. S. Diktat Kuliah “Teori Pendidikan Kristen.” Bandung: Sekolah Tinggi Alkitab Tiranus, Primo, 2008.

Sidjabat, B. S. Makalah "Desain Kurikulum." Cihanjuang: Sekolah Tinggi Alkitab Tiranus, 2008.

Stubblefield, Jerry M. A Church Ministering to Adults. Nashville: Broadman Press. 1986.

Sukmadinata, Nana Syaodih. Pengembangan Kurikulum: Teori dan Praktek. Bandung: Rosda Karya, 1997.

Wycoff, D. Campbell. Theory and Design of Christian Education Curriculum. Philadelphia: The Wesmister Press, 1961. 